\title{
Pengaruh Pendinginan Daerah Perakaran terhadap Produksi Cabai (Capsicum annuum L.) di dalam Rumah Tanaman Kawasan Tropika
}

\author{
Root Zone Cooling Affects Production of Pepper (Capcisum annuum L.) Grown in \\ Tropical Greenhouse
}

\author{
Wenny Amaliah $^{1}$, Muhamad Syukur ${ }^{2 *}$, dan Herry Suhardiyanto ${ }^{3}$
}

Diterima 05 Januari 2018/Disetujui 28 Maret 2018

\begin{abstract}
Cultivation of chili plants in the tropical greenhouse requires cooling as a solution of high temperature inside the greenhouse. One of the cooling system can be applied is root zone cooling. The aim of this research is to apply root zone cooling system to cultivation of chili plant in tropical greenhouse with substrate system, and to know the influence root zone cooling system on growth and productivity of chili plant. Plants are cultivated with a hydroponics substrate system using a drip irrigation system where the cooling pipe is buried inside the substrate medium. First treatment is cooling the root zone with cooled water and the substrate temperature of root zone cooling was 14.1$26.9^{\circ} \mathrm{C}$ (CH treatment). Second treatment is cooling the root zone with no cooled water (ambient temperature), and the substrate temperature was $24.8-34.2{ }^{\circ} \mathrm{C}$ (NC treatment). The air temperature inside greenhouse was $29.4^{\circ} \mathrm{C}$ and $24.7^{\circ} \mathrm{C}$, day and night. Due to lack of intensity of sunlight into the greenhouse, the plants sustain etiolating. However $\mathrm{CH}$ treatment produced higher fruit weight per plant compared with NC treatment. The weight of fruit per plant is $873.60 \mathrm{~g}$ and $546.00 \mathrm{~g}$, for $\mathrm{CH}$ and $N C$ respectively. The fruit size in the $\mathrm{CH}$ treatment also produced longer and heavier fruits than the NC treatment.
\end{abstract}

Keywords: hydroponics of pepper, productivity, root temperature

\begin{abstract}
ABSTRAK
Budidaya tanaman cabai di dalam rumah tanaman daerah beriklim tropis membutuhkan pendinginan sebagai solusi tingginya suhu udara di dalam rumah tanaman. Pendinginan yang dapat diterapkan salah satunya yaitu dengan pendinginan terbatas di daerah perakaran. Penelitian ini bertujuan untuk menerapkan teknik pendinginan daerah perakaran pada budidaya tanaman cabai di dalam rumah tanaman iklim tropika basah dengan sistem substrat, serta untuk mengetahui pengaruh pendinginan daerah perakaran pada pertumbuhan dan produktivitas tanaman cabai. Tanaman dibudidayakan dengan sistem hidroponik substrat dan sistem irigasi tetes yang di dalam media tanam dibenamkan pipa pendingin. Perlakuan pertama adalah pendinginan daerah perakaran dengan air yang didinginkan dan suhu media tanam yang didinginkan berkisar antara $14.1-26.9{ }^{\circ} \mathrm{C}$ (perlakuan $\mathrm{CH}$ ). Perlakuan kedua adalah pendinginan daerah perakaran dengan air yang tidak didinginkan (suhu lingkungan) dengan kisaran suhu media tanam sebesar 24.8-34.2 ${ }^{\circ} \mathrm{C}$ (perlakuan $\mathrm{NC}$ ), dengan suhu udara rata-rata $29.4{ }^{\circ} \mathrm{C}$ pada siang hari dan $24.7^{\circ} \mathrm{C}$ pada malam hari. Tanaman mengalami etiolasi akibat kurangnya intensitas cahaya matahari yang masuk ke dalam rumah tanaman. Perlakuan $\mathrm{CH}$ menghasilkan bobot buah per tanaman yang lebih tinggi dibandingkan dengan perlakuan NC. Bobot buah per tanaman sebesar $873.60 \mathrm{~g}$ dan $546.00 \mathrm{~g}$, untuk CH dan NC berturut-turut. Ukuran buah pun pada perlakuan $\mathrm{CH}$ menghasilkan buah yang lebih panjang dan lebih berat dari pada perlakuan NC.
\end{abstract}

Kata kunci: hidroponik cabai, produktivitas, suhu zona perakaran

\footnotetext{
${ }^{1}$ Mahasiswa Pascasarjana Departemen Teknik Mesin Pertanian dan Pangan, Fakultas Teknologi Pertanian, Institut Pertanian Bogor J1. Lingkar Akademik, Kampus IPB Dramaga, Bogor 16002

${ }^{2}$ Departemen Agronomi dan Hortikultura, Fakultas Pertanian, Institut Pertanian Bogor

J1. Meranti Kampus IPB Dramaga, Bogor 16680

${ }^{3}$ Departemen Teknik Mesin dan Biosistem, Fakultas Teknologi Pertanian, Institut Pertanian Bogor

Jl. Lingkar Akademik, Kampus IPB Dramaga, Bogor 16002

Email: muhsyukur@ipb.ac.id (*Penulis korespondensi)
} 


\section{PENDAHULUAN}

Cabai merupakan salah satu komoditas pertanian yang sering kali mengalami fluktuasi harga yang tajam sehingga menimbulkan berbagai implikasi yang kurang menguntungkan bagi perekonomian Indonesia. Fluktuasi harga tersebut dapat disebabkan oleh tidak seimbangnya antara produksi dan kebutuhan cabai pada suatu waktu, bahkan dapat menyebabkan terjadinya inflasi di Indonesia. Cabai merupakan salah satu komoditas yang memiliki harga yang sangat elastis terhadap pasokan (Rusono et al., 2014), yang berarti harga cabai akan sangat ditentukan oleh penawaran dan jumlah permintaan (Farid dan Subekti, 2012), oleh karena itu, fluktuasi yang tajam dalam pasokan cabai sangat penting untuk dihindarkan.

Salah satu penyebab fluktuasi pasokan cabai adalah hampir semua budidaya tanaman cabai dilakukan di lahan terbuka sehingga sangat dipengaruhi oleh cuaca. Nauli (2016) menyatakan bahwa perlu dikembangkan sistem tanam cabai di luar musim (off-season) dan pengaturan penanaman cabai sehingga mampu memenuhi kebutuhan cabai pada saat pasokan berkurang. Menurut Anwarudin et al. (2015), untuk mengurangi gagal panen di musim hujan perlu suatu teknologi budidaya cabai di rumah kasa atau rumah tanaman.

Rumah tanaman atau yang sering disebut greenhouse adalah suatu tempat dimana tanaman dapat dibudidayakan dengan memberikan kondisi yang mendekati optimum bagi pertumbuhannya (Suhardiyanto, 2009). Moekasan dan Prabaningrum (2012) melaporkan bahwa pertumbuhan tanaman cabai di dalam rumah tanaman lebih baik dibandingkan dengan tanaman yang dibudidayakan di lahan terbuka, serta memberikan keuntungan yang lebih tinggi. Daerah yang berada pada kawasan beriklim tropika, suhu udara di dalam rumah tanaman jauh lebih tinggi dibandingkan dengan suhu optimum bagi tanaman cabai, terutama pada siang hari ketika cuaca cerah. Hasil penelitian Niam (2011) menunjukkan bahwa suhu udara di dalam rumah tanaman masih di atas suhu optimum untuk tanaman cabai, sehingga diperlukan suatu upaya pendinginan di dalam rumah tanaman.

Tanaman yang berada pada kondisi suhu udara dan suhu perakaran yang tinggi, akan menurunkan laju fotosintesis (He et al., 2001). Besarnya energi yang diperlukan untuk mendinginkan seluruh volume udara di dalam rumah tanaman menjadi alasan dikembangkanlah zone cooling system sebagai energy efficient cooling system untuk rumah tanaman (Suhardiyanto, 2009). Zone cooling dapat dilakukan dengan menghembuskan udara dingin di sekitar tanaman atau dengan mengalirkan larutan nutrisi yang sudah didinginkan ke daerah perakaran tanaman (Matsuoka dan Suhardiyanto, 1992). Suhu perakaran menjadi penting karena mampu mempengaruhi aktivitas perakaran (Klock et al., 1997). Suhu perakaran yang melebihi $30^{\circ} \mathrm{C}$ akan menurunkan serapan nutrisi akar (Tindall et al., 1990). Nkansah dan Ito (1995) menyatakan bahwa pendinginan suhu perakaran mampu meningkatkan produktivitas. Pada tanaman paprika, Kwack et al. (2014) menyatakan bahwa dengan pendinginan daerah perakaran sampai suhu $28.6^{\circ} \mathrm{C}$ saat hari cerah mampu meningkatkan jumlah bunga dan mempertinggi pertumbuhan akar.

Siemonsma dan Piluek (1994) menyatakan suhu udara yang optimum untuk tanaman cabai adalah $18-30{ }^{\circ} \mathrm{C}$. Jika suhu lingkungan tanaman cabai dibawah $25{ }^{\circ} \mathrm{C}$ atau diatas $30{ }^{\circ} \mathrm{C}$ maka proses pembungaan akan terganggu. Meski demikian, suhu daerah perakaran untuk tanaman cabai belum diketahui dengan pasti. He dan Lee (1998) melaporkan bahwa suhu yang tinggi dapat mengganggu pertumbuhan tanaman dan merusak perkembangan bunga. Penelitian ini bertujuan menerapkan teknik pendinginan daerah perakaran pada budidaya tanaman cabai di dalam rumah tanaman iklim tropika basah dengan sistem substrat, serta untuk mengetahui pengaruh pendinginan daerah perakaran pada pertumbuhan dan produktivitas tanaman cabai.

\section{BAHAN DAN METODE}

Penelitian dilaksanakan pada bulan Desember 2015 sampai Desember 2016 di rumah tanaman tipe modified standard peak, bertempat di Laboratorium Lapangan Siswadi Soeparjo, Departemen Teknik Mesin dan Biosistem, Institut Pertanian Bogor. Bahan yang digunakan dalam penelitian yaitu benih cabai merah keriting varietas Yuni-IPB, larutan nutrisi $\mathrm{AB}$ mix, media tanam berupa campuran 
arang sekam dan cocopeat dengan perbandingan 4:1 dan ketebalan $24 \mathrm{~cm}$ dari dasar bak tanam. Alat yang digunakan yaitu tray persemaian untuk menyemai benih cabai, chamber media tanam hidroponik substrat dengan pipa pendingin yang dibenamkan di dalamnya, pompa air untuk mengalirkan air pendingin, sistem irigasi tetes, chiller untuk mendinginkan air, termokopel dan hybrid recorder untuk merekam suhu,weather station untuk mengukur iklim mikro di dalam rumah tanaman, serta EC meter untuk mengukur tingkat EC dari larutan nutrisi.

Benih disemaikan selama 6-9 minggu, kemudian dipindah tanam di rumah tanaman. Chamber berukuran $125 \mathrm{~cm} \times 625 \mathrm{~cm} \times 25 \mathrm{~cm}$. Jarak tanam dengan ukuran $40 \mathrm{~cm}$ x $50 \mathrm{~cm}$. Larutan nutrisi diberikan pada tanaman melalui sistem irigasi tetes sebanyak 3 kali dalam seminggu dengan konsentrasi EC 3.0 - $3.2 \mathrm{mS}$ (Resh, 2004). Irigasi tanaman pada fase vegetatif usia 1-5 minggu setelah tanam (MST) diberikan air sebanyak 600 ml.tanaman-1.hari-1 ${ }^{-1}$, fase berbunga (6-8 MST) sebanyak 900 ml.tanaman ${ }^{-1}$.hari ${ }^{-1}$, dan pada fase pematangan buah (>8 MST) diberikan air 1500 ml.tanaman ${ }^{-1}$. hari $^{-1}$ (Tim penulis AgriFlo, 2012).

Budidaya tanaman cabai pada penelitian ini diberikan dua perlakuan, yaitu pendinginan media tanam dengan air yang didinginkan menggunakan chiller yang suhu di set-up sebesar $14{ }^{\circ} \mathrm{C}$ (perlakuan $\mathrm{CH}$ ), serta perlakuan media tanam yang pada pipa pendinginnya dialirkan air yang tidak didinginkan atau sesuai suhu lingkungan (perlakuan NC). Setiap bak tanam terdapat sembilan pipa yang saling tersambung. Pipa pendingingin terbuat dari pipa galvanis berdiameter $19 \mathrm{~mm}$. Air pendingin dialirkan ke pipa pendingin yang dibenamkan di dalam media tanam dengan kedalaman 10-12 cm dari permukaan media tanam. Air pendingin disirkulasikan sepanjang hari (siang-malam) di dalam pipa pendingin. Setiap perlakuan menggunakan satu bak tanam yang masing-masing terdapat 36 tanaman. seluruh tanaman tersebut digunakan sebagai sampel pengamatan yang terbagi menjadi enam ulangan dengan setiap ulangan terdapat sebanyak enam tanaman.

Suhu air pendingin pada bagian inlet dan outlet, suhu media tanam, suhu permukaan tanaman, suhu shoot zone, serta suhu udara di dalam rumah tanaman diukur dengan termokopel yang direkam dengan hybrid recorder sepanjang hari. Pengukuran suhu udara meliputi bagian atas, tengah, dan bawah rumah tanaman, serta pada bagian depan dan belakang di dalam rumah tanaman. Pengukuran suhu media tanam secara vertikal pada ketinggian $6 \mathrm{~cm}, 12 \mathrm{~cm}$, dan $18 \mathrm{~cm}$ dari dasar media tanam, serta secara horisontal dengan jarak $3.5 \mathrm{~cm}$ dan $7 \mathrm{~cm}$ dari pipa (pada posisi kedalaman $12 \mathrm{~cm}$ ). Hasil pengukuran suhu pada media tanam tersebut kemudian dirata-ratakan sebagai suhu media tanam untuk setiap waktu pengukuran. Peubah yang diamati umur awal berbunga, tinggi tanaman, umur awal panen, bobot buah, panjang buah, jumlah buah per tanaman, dan bobot buah pertanaman. Data hasil penelitian dianalisis secara statistika menggunakan software SAS uji T dengan taraf beda nyata 5\%. Pada peubah yang berbeda nyata kemudian dilanjutkan dengan analisis korelasi dengan software STAR 2.0.1 untuk mengetahui pengaruh antar peubah.

\section{HASIL DAN PEMBAHASAN}

\section{Suhu}

Selama penelitian budidaya tanaman cabai dengan teknik pendinginan daerah perakaran, suhu rata-rata siang hari mencapai $29.4{ }^{\circ} \mathrm{C}$ dan malam hari $24.7{ }^{\circ} \mathrm{C}$, namun di dalam rumah tanaman pada siang hari suhu udara sangat tinggi bahkan dapat mencapai 48 ${ }^{0} \mathrm{C}$ (Tabel 1). Suhu maksimal di dalam rumah tanaman yang cukup tinggi tersebut diperoleh dari hasil pengukuran suhu udara di bagian atas rumah tanaman (terdekat dengan atap rumah tanaman). Cuaca yang panas di luar rumah tanaman mempengaruhi tingginya suhu udara di dalam rumah tanaman. Keadaan ini terjadi saat bulan Maret dan April yang mana pada bulan-bulan tersebut rata-rata suhu udara cukup tinggi di daerah tempat penelitian.

Suhu rata-rata media tanam (root-zone) diperoleh dari hasil rata-rata suhu yang terukur pada beberapa titik pada media tanam. Suhu rata-rata media tanam untuk perlakuan $\mathrm{CH}$ sebesar $19.8{ }^{\circ} \mathrm{C}$ dan perlakuan NC sebesar 28.3 ${ }^{0} \mathrm{C}$. Kisaran suhu pada media tanam selama budidaya tanaman masing-masing sebesar 14.1-26.9 ${ }^{0} \mathrm{C}$ untuk $\mathrm{CH}$ dan $24.8-34.2{ }^{\circ} \mathrm{C}$ untuk NC (Gambar 1). Suhu media tanam pada perlakuan $\mathrm{CH}$ lebih rendah dari perlakuan $\mathrm{NC}$ disebabkan adanya pindah panas antara media 
tanam dengan pipa pendingin dan air pendingin. Panas dari udara di dalam rumah tanaman berpindah ke bak tanam atau media tanam secara konveksi yang kemudian diteruskan pada pipa pendingin yang memiliki suhu lebih rendah dari media tanam secara konduksi dan akhirnya panas tersebut sampai pada air pendingin secara konveksi. Panas yang berpindah tersebut menyebabkan naiknya suhu air pendingin dan suhu media tanam menjadi lebih rendah sampai terjadinya keseimbangan suhu. Posisi pipa pendingin yang menyebar merata pada media tanam tersebut mampu mendinginkan media tanam secara meluas.

Suhu media tanam yang fluktuatif dipengaruhi oleh suhu udara di dalam rumah tanaman. Pada siang hari, rumah tanaman mendapat pancaran sinar matahari yang mengakibatkan meningkatnya suhu udara yang menyebabkan suhu permukaan media tanam meningkat akibat perpindahan panas dari udara ke dalam media tanam, sehingga meskipun media tanam didinginkan tetap terjadi peningkatan suhu. Gambar 1 menunjukkan bahwa suhu media tanam yang didinginkan dengan air bersuhu lingkungan pada malam hari lebih tinggi dari suhu udara. Hal ini dikarenakan air memiliki panas jenis yang lebih tinggi dari udara, sehingga untuk menurunkan suhu air membutuhkan waktu yang lebih lama dibandingkan dengan menurunkan suhu udara. Kondisi tersebut menyebabkan suhu media tanam lebih konstan dibandingkan dengan suhu udara di dalam rumah tanaman.

\section{Tinggi Tanaman}

Tinggi tanaman untuk kedua perlakuan diperoleh tanaman yang sangat tinggi (Gambar 3 ), berbeda dengan hasil penelitian Pangestika (2015) menyatakan bahwa tinggi rata-rata tanaman cabai varietas Yuni-IPB hanya mencapai $44.2 \mathrm{~cm}$. Perbedaan tinggi yang sangat jauh disebabkan adanya gejala etiolasi pada tanaman yang dibudidayakan di dalam rumah tanaman. Gejala etiolasi disebabkan oleh kurangnya intensitas cahaya matahari yang masuk ke dalam rumah tanaman akibat terhalang oleh atap rumah tanaman yang sudah tidak transparan seperti kondisi awal karena adanya kotoran/lumut yang menempel pada atap, sehingga gejala etiolasi tersebut terjadi pada seluruh tanaman penelitian.

Tabel 1. Suhu rata-rata udara rumah tanaman pada bulan Maret - Desember 2016

\begin{tabular}{lcccc}
\hline \multirow{2}{*}{ Bulan } & \multicolumn{2}{c}{ Suhu Rata-rata $\left({ }^{0} \mathrm{C}\right)$} & $\begin{array}{c}\text { Suhu Maksimal } \\
\left({ }^{0} \mathrm{C}\right)\end{array}$ & $\begin{array}{c}\text { Suhu Minimal } \\
\left({ }^{0} \mathrm{C}\right)\end{array}$ \\
\cline { 2 - 3 } & Siang & Malam & 48.3 & 20.6 \\
Maret & 30.7 & 25.0 & 48.5 & 20.6 \\
April & 29.9 & 25.2 & 38.9 & 20.7 \\
Mei & 29.2 & 25.6 & 40.4 & 19.7 \\
Juni & 29.1 & 24.6 & 39.9 & 20.5 \\
Juli & 29.1 & 24.4 & 36.3 & 19.9 \\
Agustus & 28.6 & 24.4 & 39.2 & 20.9 \\
September & 28.7 & 24.4 & 37.4 & 20.6 \\
Oktober & 28.5 & 24.4 & 38.5 & 21.3 \\
November & 28.3 & 24.4 & & 20.6 \\
Desember & 27.9 & 24.0 & 36.9 & \\
\hline
\end{tabular}

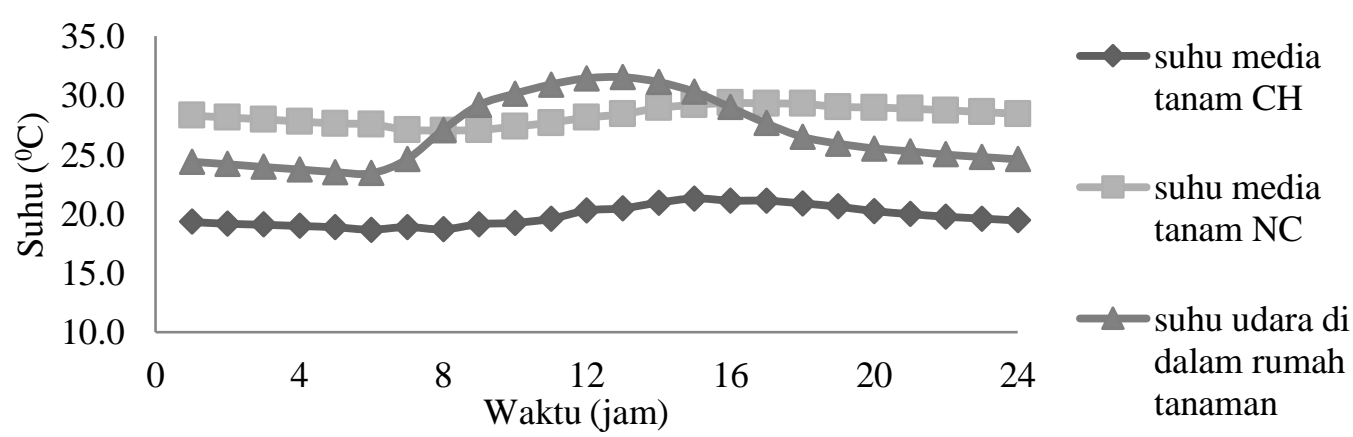

Gambar 1. Grafik suhu setiap waktu hasil rata-rata selama penelitian 
Sitompul dan Guritno (1995) menyatakan bahwa parameter tinggi tanaman cukup sensitif terhadap faktor lingkungan tertentu terutama cahaya sehingga jika tanaman kekurangan cahaya maka pertumbuhan tanaman akan lebih tinggi dari tanaman yang mendapatkan cukup cahaya.

Tanaman cabai merupakan salah satu jenis tanaman yang membutuhkan sinar matahari secara penuh (Acquaah, 2004), sehingga pada kondisi di bawah naungan pertumbuhan akan terganggu. Hal ini disebabkan oleh hormon pertumbuhan tanaman, yaitu hormon auksin, terutama indoleacetic acid (IAA). Pada keadaan gelap, IAA akan terakumulasi dan tingginya konsentrasi IAA ini akan mempercepat pertumbuhan terutama tinggi tanaman. Tampak pada Tabel 2 rata-rata tinggi akhir tanaman cabai pada kedua perlakuan cukup berbeda, namun tidak signifikan pada taraf uji 5\%.

\section{Umur Berbunga}

Hasil uji T menunjukkan umur berbunga pada kedua perlakuan tidak berbeda secara signifikan (Tabel 2). Umur panen pertama perlakuan $\mathrm{CH}$ lebih cepat 14 hari dibandingkan perlakuan NC, meskipun berdasarkan hasil uji tidak menunjukkan perbedaan yang signifikan. Hal ini dapat menjadi indikasi bahwa pendinginan daerah perakaran dapat mempercepat pembungaan dan pembuahan.

Dibandingkan dengan hasil penelitian Pangestika (2015), umur panen pada penelitian cukup lambat. Menurut Siemonsma dan Piluek (1994) bunga mekar membutuhkan waktu 2-3 hari, kemudian bunga akan menjadi bakal buah dan buah pertama muncul hingga matang hanya membutuhkan umur 4-5 minggu setelah berbunga. Pada penelitian ini, umur berbunga tanaman cabai pada kedua perlakuan tidak ada keterlambatan, hanya saja waktu yang dibutuhkan dari awal berbunga hingga awal panen mencapai sekitar 10 minggu dan 12 minggu untuk perlakuan $\mathrm{CH}$ dan $\mathrm{NC}$ berturutturut. Keterlambatan umur panen disebabkan banyaknya bunga dan bakal buah yang rontok karena mengering akibat tingginya suhu udara di dalam rumah tanaman. Hasil tersebut sesuai dengan pernyataan Sato et al. (2006), suhu udara yang tinggi menyebabkan menurunnya viabilitas bunga dan pelepasan serbuk sari.

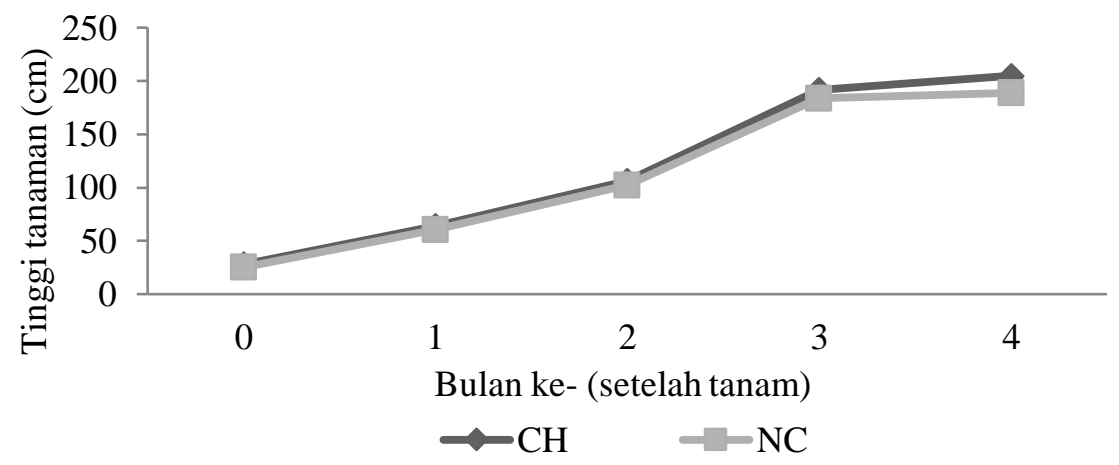

Gambar 2. Grafik pertumbuhan tanaman cabai Yuni-IPB

Tabel 2. Pertumbuhan tanaman dan produktivitas pada masing-masing perlakuan

\begin{tabular}{lrrr}
\hline \multicolumn{1}{c}{ Peubah } & \multicolumn{1}{c}{ CH } & NC & KK (\%) \\
\hline Tinggi Tanaman (cm) & $204.9 \mathrm{a}$ & $188.8 \mathrm{a}$ & 8.18 \\
Umur Awal Berbunga (HST) & $12.0 \mathrm{a}$ & $15.0 \mathrm{a}$ & 25.72 \\
Umur Awal Panen (HST) & $83.0 \mathrm{a}$ & $97.0 \mathrm{a}$ & 19.30 \\
Bobot Buah (g) & $4.28 \mathrm{a}$ & $3.95 \mathrm{~b}$ & 6.00 \\
Panjang Buah (cm) & $15.2 \mathrm{a}$ & $14.4 \mathrm{~b}$ & 2.12 \\
Bobot Total Buah per Tanaman (g) & $873.6 \mathrm{a}$ & $546.0 \mathrm{~b}$ & 16.00 \\
Jumlah Buah per Tanaman & $253.9 \mathrm{a}$ & $157.3 \mathrm{~b}$ & 17.14 \\
\hline
\end{tabular}

Keterangan: Angka-angka yang diikuti huruf yang sama pada baris yang sama menunjukkan tidak berbeda nyata berdasarkan uji T pada taraf $\alpha=5 \%$; KK: koefisien keragaman; $\mathrm{CH}$ : perlakuan dengan suhu media tanam 14.1-26. ${ }^{\circ} \mathrm{C}$; NC: perlakuan dengan suhu media tanam $24.8-34.2{ }^{\circ} \mathrm{C}$. 
Sasaki et al. (2005) pun melaporkan bahwa suhu yang tinggi menyebabkan keterlambatan pembentukan buah. Keterlambatan panen buah tampak pada Gambar 4 dan Gambar 5 , tanaman banyak berbuah mulai bulan keempat setelah tanam. Suhu udara mulai menurun pada bulan Agustus dan hasil panen mulai meningkat. Bulan Desember hasil panen sudah sangat menurun disebabkan beberapa tanaman sudah mulai terserang hama bahkan beberapa tanaman mulai layu dan mati.

\section{Ukuran Buah}

Bobot dan panjang buah antara perlakuan $\mathrm{CH}$ dan $\mathrm{NC}$ menunjukkan perbedaan yang signifikan dengan taraf uji 5\% (Tabel 2). Bobot buah dan panjang buah ini pun lebih dari hasil buah cabai yang ditanam di lahan terbuka dengan varietas yang sama oleh Pangestika (2014) yang hanya mencapai $3.0 \mathrm{~g}$ dan panjangnya $12.51 \mathrm{~cm}$ untuk varietas Yuni-IPB. Sumarni et al. (2013) menyatakan rata-rata bobot umbi kentang terbesar pada pendinginan zona perakaran bersuhu $10{ }^{\circ} \mathrm{C}$ dibandingkan dengan pendinginan perakaran bersuhu $15^{\circ} \mathrm{C}$ dan $20^{\circ} \mathrm{C}$.

Hasil yang sama diungkapkan oleh Sakamoto et al. (2016), dengan suhu udara 20 ${ }^{0} \mathrm{C}$, pada perlakuan pendinginan daerah perakaran hingga suhu $10{ }^{\circ} \mathrm{C}$ dihasilkan buah stroberi yang lebih berat dari pada perlakuan suhu perakaran sebesar $20{ }^{\circ} \mathrm{C}$ meskipun tidak signifikan dengan taraf uji 0.05 , dan untuk perlakuan suhu $30{ }^{\circ} \mathrm{C}$ tidak dapat ditentukan karena banyaknya tanaman yang layu. Hasil dari penelitian ini pun menunjukkan pendinginan perakaran mampu meningkatkan bobot buah dan panjang rata-rata buah cabai.

\section{Produktivitas}

Hasil panen cabai per tanaman menunjukkan perbedaan yang signifikan pada taraf uji 5\% dengan perlakuan $\mathrm{CH}$ menghasilkan total bobot maupun jumlah buah lebih tinggi dari perlakuan NC. Gambar 4 dan Gambar 5 menunjukkan hubungan bahwa jumlah buah per tanaman sebanding dengan bobot buah per tanaman yang pada perlakuan pendinginan zona perakaran dengan air dingin menghasilkan jumlah dan juga bobot lebih tinggi dibandingkan dengan pendinginan zona perakaran dengan air bersuhu lingkungan. Hasil tersebut dapat mengindikasikan bahwa pendinginan perakaran mampu meningkatkan produktivitas tanaman. Hasil ini senada dengan pernyataan Sumartono dan Sumarni (2013), dengan pendinginan perakaran sepanjang hari mampu menghasilkan jumlah umbi kentang yang terbanyak.

Tan et al. (2002) menjelaskan bahwa suhu perakaran yang didinginkan mampu menghasilkan akar yang lebih panjang dan lebih besar dari pada akar yang tidak didinginkan. Hasil penelitian Kawasaki et al. (2013) menunjukkan pendinginan daerah perakaran dengan suhu rata-rata perakaran 24.7 ${ }^{0} \mathrm{C}$ pada tanaman tomat mampu mempengaruhi morfologi akar yaitu pembuluh xilem pada ujung akar lebih berkembang dibandingkan dengan tanaman yang suhu akarnya $33.7^{\circ} \mathrm{C}$. Menurut Dian-Perez (2009) serta Baghhour et al. (2002), suhu perakaran mampu mempengaruhi proses fisiologi pada akar, seperti proses penyerapan mineral dan nutrisi dari media tanam melalui akar. Klock et al. (1997) menyatakan dengan pendinginan perakaran mampu meningkatkan penyerapan air dan nutrisi serta meningkatkan laju respirasi akar. Tanaman menyerap nutrisi dari media tanam melalui akar, dengan akar yang lebih panjang dan lebih besar, maka akan memperluas permukaan serapan nutrisi tanaman sehingga tanaman memperoleh nutrisi yang lebih banyak.

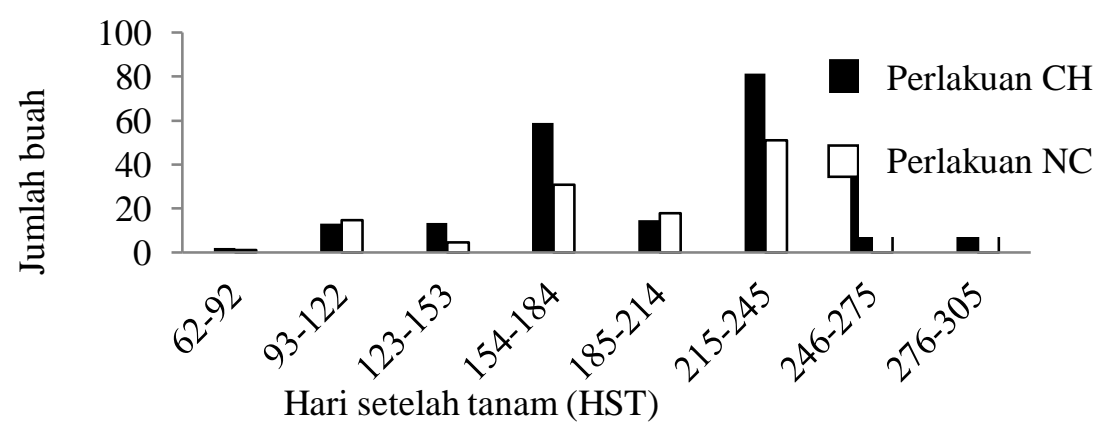

Gambar 4. Rata-rata total panen buah cabai per tanaman setiap bulan. 


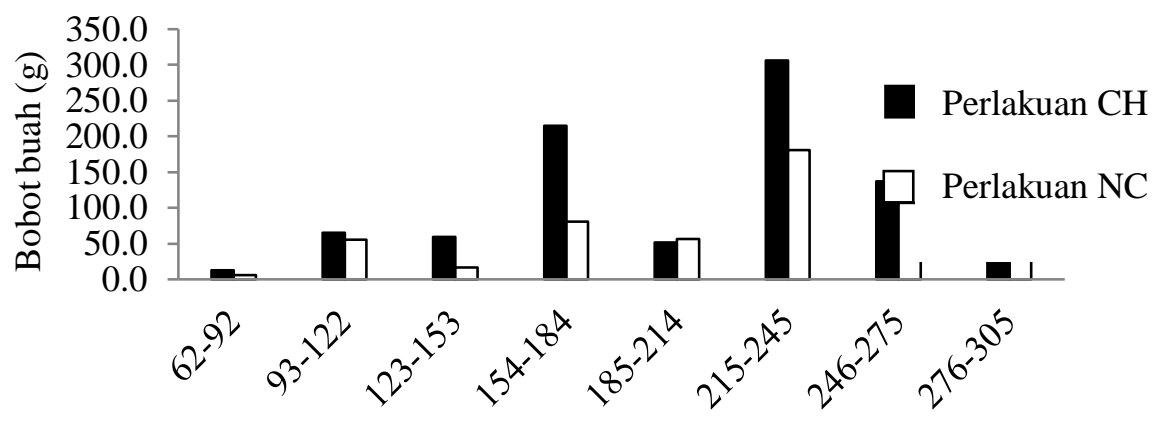

Hasi setelah tanam (HST)

Gambar 5. Rata-rata total bobot buah cabai per tanaman setiap bulan.

He dan Lee (1998) melaporkan bahwa suhu daerah perakaran yang rendah mampu menurunkan suhu daun yang kemudian mampu meningkatkan laju fotosintesis pada tanaman Lactuca sativa L., meskipun pada suhu udara yang tinggi. Tanaman cabai merupakan salah satu jenis tanaman $\mathrm{C} 3$, dimana tanaman $\mathrm{C} 3$ memiliki karakter laju fotosintesis akan meningkat dengan suhu daun yang rendah. Nkasah dan Ito (1995) juga menjelaskan bahwa suhu perakaran yang rendah mampu meningkatkan aktivitas fotosintesis pada tanaman. Laju fotosintesis yang meningkat menghasilkan fontositat yang lebih tinggi, sehingga mampu meningkatkan produktivitas tanaman, baik bobot buah maupun jumlah buah per tanaman.

Pengamatan lebih lanjut pada Gambar 4 dan Gambar 5 menunjukkan bahwa tanaman cabai mulai banyak berbuah setelah bulan keempat setelah tanam atau 93 HST pada kedua perlakuan, yang seharusnya cabai sudah dapat dipanen pada 70-75 HST (Wardani dan Purwanta 2008). Tanaman mulai banyak berbuah dan tidak banyak yang rontok saat memasuki bulan Juni yang pada saat itu tanaman sudah tinggi (Gambar 3) dan rimbun, sehingga suhu udara di sekitar shoot zone mulai menurun meskipun suhu udara rata-rata di dalam rumah tanaman masih cukup tinggi seperti yang ditunjukkan pada Tabel 1. Suhu udara di dalam rumah tanaman yang semakin menurun setiap bulannya cukup berpengaruh pada perkembangan bunga dan buah. Hal ini menunjukkan bahwa suhu udara masih cukup mempengaruhi pertumbuhan buah cabai selain pengaruh dari pendinginan daerah perakaran itu sendiri.

\section{Analisis Korelasi}

Berdasarkan hasil dari uji $\mathrm{T}$ dengan taraf kepercayaan 5\%, diketahui bahwa peubah yang berbeda secara nyata antara kedua perlakuan yakni bobot buah, panjang buah, jumlah buah per tanaman, dan bobot total buah per tanaman. Selanjutnya, dilakukan analisis korelasi untuk mengetahui tingkat saling keterkaitan antar peubah. Hasil analisis menunjukkan bahwa masing-masing peubah saling berkorelasi positif meskipun tidak semua berbeda nyata pada taraf 5\% (Tabel 3).

Tampak pada Tabel 3 bahwa bobot buah memiliki korelasi positif secara signifikan dengan panjang buah dan jumlah buah memiliki korelasi positif dengan sangat signifikan (taraf $1 \%)$. Hasil ini sesuai dengan pernyataan Sharma et al. (2010) bahwa jumlah buah per tanaman memiliki korelasi positif dengan bobot buah per tanaman. Bobot buah dan panjang buah meskipun memiliki korelasi positif terhadap jumlah buah dan bobot buah namun tidak berbeda nyata pada taraf 5\%. Hal tersebut dapat disebabkan karena bobot buah dan panjang buah memiliki pengaruh yang tidak langsung terhadap bobot buah per tanaman melalui jumlah buah (Syukur et al., 2010).

Tabel 3. Nilai korelasi antar peubah

\begin{tabular}{lccc}
\hline \multicolumn{1}{c}{ Peubah } & Panjang Buah & Jumlah Buah & Bobot Buah per Tanaman \\
\hline Bobot Buah & $0.62^{*}$ & 0.39 & 0.51 \\
Panjang Buah & - & 0.49 & 0.51 \\
Jumlah Buah Per Tanaman & - & - & $0.99^{* *}$ \\
\hline
\end{tabular}

Keterangan: *=berkorelasi nyata pada taraf $5 \%, * *=$ berkorelasi sangat nyata pada taraf $1 \%$. 


\section{KESIMPULAN}

Penelitian ini menunjukkan pendinginan terbatas di daerah perakaran memberi pengaruh pada tinggi tanaman, mempercepat umur berbunga dan umur panen meskipun tidak signifikan. Pendinginan daerah perakaran pada tanaman cabai juga secara signifikan mampu meningkatkan bobot buah, panjang buah, jumlah buah per tanaman, dan bobot buah per tanaman. Bobot buah per tanaman secara positif berkorelasi dengan bobot buah, panjang buah, serta jumlah buah per tanaman.

\section{DAFTAR PUSTAKA}

Acquaah, G. 2004. Horticulture: Principles and Practices 3rd edition. Pearson Education, New Jersey.

Anwarudin, M.J., A.L. Sayekti, A.K. Marendra, Y. Hilman. 2015. Dinamika produksi dan volatilitas harga cabai: antisipasi strategi dan kebijakan pengembangan. Pengembangan Inovasi Pertanian. 8(1): $33-42$.

Baghour, M., D.A. Moreno, G. Villora, I.L. Cantarero, J. Hernandez, N. Castilla, L. Romero. 2002. Root-zone temperature influences the distribution of $\mathrm{Cu}$ and $\mathrm{Zn}$ in potato-plant organs. J. Agric. Food Chem. 50: 140-146.

He, J., S.K. Lee. 1998. Growth and photosynthetic characteristics of lettuce (Lactuca sativa $\mathrm{L}$.) under fluctuating hot ambient temperatures with the manipulation of cool root-zone temperature. J. Plant Physiology 152: 387-391.

He, J., S.K. Lee, I.C. Dodd. 2001. Limitations to photosynthesis of lettuce grown under tropical condition: alleviation by rootzone cooling. J. Exp. Bot. 52(359): 1323-1330.

Diaz-Pérez, J.C. 2009. Root zone temperature, plant growth and yield of broccoli [Brassica oleracea (Plenck) var. Italica] as affected by plastic film mulches. J. Sci. Hort. 123(2): 156-163.
Farid, M., N.A. Subekti. 2012. Tinjauan terhadap produksi, konsumsi, distribusi, dan dinamika harga cabai di Indonesia. Buletin Ilmiah Litbang Perdagangan 6(2): 211-233.

Kawasaki, Y., S. Matsuo, K. Suzuki, Y. Kanayama, K. Kanahama. 2013. Rootzone cooling at high air temperatures enhances physiological activities and internal structures of roots in young tomato plants. J. Japan. Soc. Hort. Sci. 82(4): 322-327.

Klock, K.A., H.G. Taber, W.R. Graves. 1997. Root respiration and phosphorus nutrition of tomato plant grown at $36{ }^{\circ} \mathrm{C}$ root-zone temperature. J. Amer. Soc. Hort. Sci. 122(2): 175-178.

Kwack, Y., D.S. Kim, C. Chun. 2014. Rootzone cooling affect growth and development of paprika transplants grown in rockwool cubes. Hort. Environ. Biotechnol. 55(1): 14-18.

Matsuoka, T., H. Suhardiyanto. 1992. Thermal and flowing aspects of growing petty tomato in cooled NFT solution during summer. Environ. Control in Bio. 30(3): 119-125.

Moekasan, T.K., L. Prabaningrum. 2012. Penggunaan rumah kasa untuk mengatasi serangan organisme pengganggu tumbuhan pada tanaman cabai merah di dataran rendah. J. Hort. 22(1): 66-76.

Nauli, D. 2016. Fluktuasi dan disparitas harga cabai di Indonesia. J. Agrosains dan Teknologi. 1(1): 56-69.

Niam, A.G. 2011. Simulasi distribusi suhu dan pola pergerakan udara pada rumah tanaman tipe standard peak berventilasi mekanis menggunakan CFD. [Tesis]. Institut Pertanian Bogor. 81 hal.

Nkansah, G.O., T. Ito. 1995. Effect of air and root-zone temperatures on physiological characteristics and yield of heat-tolerant and non heat-tolerant tomato cultivar. J. Japan. Soc. Hort. Sci. 64(2): 315-320. 
Pangestika, H.W. 2015. Evaluasi pendahuluan galur cabai keriting (Capsicum anпиит L.). Skripsi. Institut Pertanian Bogor. Bogor. 19 hal.

Resh, H.M. 2004. Hydroponic Food Production: a Difinitive Guidebook of Soilless Food-Growing Methods 6th Ed. Newconcept press, New Jersey.

Rusono, N., A. Suanri, A. Candradijaya, A, Muharam, I. Martino, Tejaningsing, P.U. Hadi, S.H. Susilowati, M. Maulana. 2014. Studi Pendahuluan: Rencana Pembangunan Jangka Menengah Nasional (RPJMN) Bidang Pangan dan Pertanian 2015-2019. Direktorat Pangan dan Pertanian, Kementerian Perencanaan Pembanganunan Nasional, Jakarta.

Sakamoto, M., M. Uenishi, K. Miyamoto, T. Suzuki. 2016. Effect of root-zone temperature on the growth and fruit quality of hydroponically grown strawberry plants. J. Agricultural Science. 8(5): 122-131.

Sasaki, H., T. Yano, A. Yamasaki. 2005. Reduction of high temperature inhibition in tomato fruit set by plant growth regulators. JARQ. 39(2): 135-138.

Sato, S., M. Kamiyama, T. Iwata, N. Makita, H. Furukawa, H. Ikeda. 2006. Moderate increase of mean daily temperature adversely affect fruit set of Lycopersicon esculentum by disrupting specific physiological processes in male reproductive development. Ann. Bot. 97: 731-738.

Sharma, V.K., C.S. Semwal, S.P. Uniyal. 2010. Genetic variability and character association analysis in bell pepper (Capsicum annuиm L.). J. Hort. For. 2(3): 058-065.

Siemonsma, J.S., K. Piluek. 1994. Plant Resources of South-East Asia, No.8, Vegetables. Prosea Foundation, Bogor.
Sitompul, S.M., B. Guritno. 1995. Analisis Pertumbuhan Tanaman. Gadjah Mada University Press, Yogyakarta.

Suhardiyanto, H. 2009. Teknologi Rumah Tanaman untuk Iklim Tropika Basah: Pemodelan dan Pengendalian Lingkungan. IPB Press, Bogor.

Sumarni, E., H. Suhardiyanto, K.B. Seminar, S.K. Saptomo. 2013. Pendinginan zona perakaran (root zone cooling) pada produksi benih kentang menggunakan sistem aeroponik. J. Agron. Indonesia. 41(2): 154-159.

Sumartono, G.H., E. Sumarni. 2013. Pengaruh suhu media tanam terhadap pertumbuhan vegetatif kentang hidroponik di dataran medium tropika basah. J. Agronomika. 13(1): 1-9.

Syukur, M., S. Sujiprihati, R. Yunianti, K. Nida. 2010. Pendugaan komponen ragam, heritabilitas dan korelasi untuk menentukan kriteria seleksi cabai. J. Hort. Indonesia. 1(3): 74-80.

Tan, L.P., J. He, S.K. Lee. 2002. Effect of rootzone cooling temperature on the root development and nutrient uptake of Lactuca sativa L. "panama" grown in an aeroponic system in the tropics. Journal of Plant Nutrition. 25(2): 297-314.

[Tim Penulis AgriFlo]. 2012. Cabai: Prospek Bisnis dan Teknologi Mancanegara. Agriflo, Jakarta.

Tindall, J.A., H.A. Mills, D.E. Radcliffe. 1990. The effect of root zone temperature on nutrient uptake of tomato. J. Plant. Nutr. 13(8): 939-956.

Wardani, N., Purwanta, J.H. 2008. Teknologi Budidaya Cabai Merah. Balai Besar Pengkajian dan Pengembangan Teknologi Pertanian, Badan Penelitian dan Pengembangan Pertanian, Bogor. 